\title{
骨髄組織培養法飞上る諸種血液疾患患者 骨䯣巨核球機能に関する研究
}

\author{
第 2 編 \\ 諸種血液疾患々者骨髄巨核球機能に就いて \\ 剛山大学医学部平木内科教室（主任：平木 橴教授） \\ 䙳攻生 佐々 木 邦 朗
}

[昭和 33 年 7 月 7 日受稿〕

第1章 緒 言

第 2 章 実験材料並びに実験方法

第 1 節 実験材料

第 2 節 実験方法

第 3 章 実験成績

第 1 節 煡 康人

第 2 節 単純性紫理病

第3節 バンチ氏病

\section{第1章 粕言}

諸種血液突患々者の胃骮巨核球に関する研究は, 柽球数が劇的に減少して，著明な出血傾向の出現す るウェルホーフ氏病を、心に，その他㞗々出血が死 因となる再生不良性頜血，白血病等流き古くから 行われている.然し乍ら從来の研究は，胃䯣巨核球と 栓球数の数量的相関閔係汇就いての報告が殆んどで ある. 即ち，Frey 22)，福井36)等は骨䯣組織切片標本て，

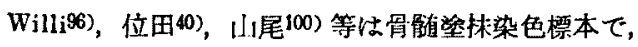
又岡部70)，Evangh and Bird19)，林田64) 等认胃随 穿刺液を計算盤で算定する方法を以つて各種将出に 就いて詳湅化報告している。

一方骨膸巨核球の機能に関しては，第 1 編に於て す述へた如く Wright98) が烃球形成に就いて発表

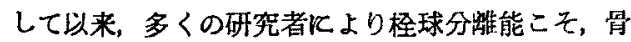
餚巨核球の最も重要な機能の一つとして認められて 来たが，その後この方面の研究は殆んど発展を見せ なかつた。

此の巨核球機能学の発展を阻止した最大の原因は，

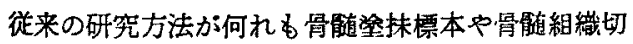

容目次

\begin{tabular}{|c|c|}
\hline 第 4 節 & 再生不良性分血 \\
\hline 第 5 節 & 症候性栓球增多症 \\
\hline 第 6 節 & 悪性賓血 \\
\hline 第 7 節 & 無顆柆紐胞症 \\
\hline 第 8 節 & 本態性低色素性賽血 \\
\hline 第 9 節 & 慢性失血性盆血 \\
\hline 第4 章 & 急括站ひに考案 \\
\hline 第 5 章 綂 & 吉読 \\
\hline
\end{tabular}

片標本による，死後染色標本の観察に終始して，動 熊観察を欠いだ為であろう。乙の後 Rich76)，位 田(0), 前/原61)，栗原58)，滝川87)等により，超生体 観察法や組織培溶法が取り上げられたのも，かかる 見地からであるが，これ等の方法を用いても骨睢巨 核珪が余りにを大きく，障碍を受け易いこと及び培

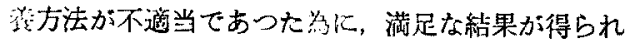
なかつた。

所が最近，教室の角南，粟井5)30331125)等は従来の 組織培距法を改良した結果，骨骮过巨核球が可成り活

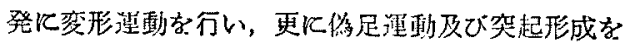
行い，その做手状突起の尖端から栓球を分離する像

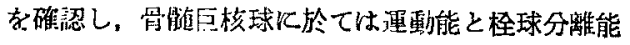
が梌めて密接，不可分の関係䎲有る事を認めている. その後 Bessis6)88)，Albrecht2) 等別個に類似し た契験を行い，同様の結果を埌告している。

私はこの組䋨培洨法を踇床的に応用して, 諸種血 液疾患々者の胃艏巨核球機能を枱索した結果，興味 ある所見を得たので報告する。 


\section{第 2 章 实䀫材料过ひに実医方法}

\section{第 1 第 実験材料}

(1) 骨髄組糤片の探取

柽球数に全く異常を認めない健康人男女 5 人宛, 及び当教室に入院せる諸種血液疾患々者（単純性紫 病 5 人，バンチ氏病 8 人，再生不良性寊血13人，

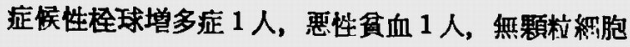
症 2 人，本悲性低色素性貫血 7 人，及び慢性失血寊 血3人）40人に就き検査した.

先づ隇菌消毒せる小宮式骨䯣穼制針飞て胸骨骨稙

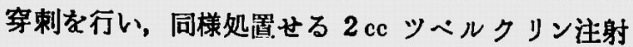

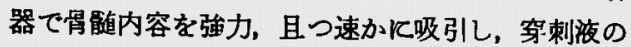
一部を,骨髄盗抹標本の作製及び単位容積 $\left(1 \mathrm{~mm}^{3}\right)$ 中 の巨核球数の算定に用い, 残りを隇菌ン+ーレに入 れ、冒能組織片る取り出し、リンダル氏液で充分と 末梢血を洗い流して実験に用いた。

(2) 趾康人ヘパリン加血整

早朝空腹時, 健康人の肘静脈より，1000倍へパリ ン約 $0.1 \mathrm{cc}$ を吸引した注射器飞て約 $10 \mathrm{cc}$ 採血し, 充分混和した後，小試験管に取り，2000回転15分間 遠心沈没し，上部の血筤部分を用いた。

(3) 鴌胎压推液

躬化後 9 日目の受精卵より鷄胎を取り出してリン

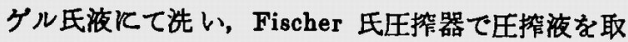
り，2000回転，30分間遠心沈泎し，上澄液を取り， リンダル氏液と等量に混じて用いた。

(4) 培養器 (第 1 泪)

図《示す如き海野氏穴あきガラス（厚さ $0.9 \mathrm{~mm}$ の载物ガラスの中央に直径 $20.0 \mathrm{~mm}$ の円形の穴を 打ち抜いたるの）の片面にカナタ・バサムを䀡付

第 1 図培韵器

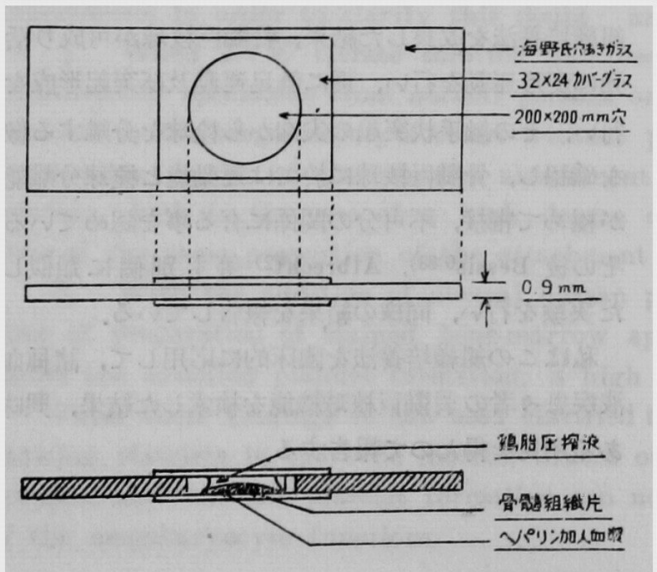

したものを用いた。

\section{第 2 第 実験方法}

(1) 末梢血検查法

一般血液検查に準じて行い，栓球数は Fonio 氏 間接法によつて検査した。

(2) 単位容積 $\left(1 \mathrm{~mm}^{3}\right)$ 中の巨核球数

胸骨骨髄穿刺液を白血球メランシュールKて吸引 乙白血球数測定々同梾飞 Tuirk 氏液で稀粎し，充 分振逜湜和した後，有核紏胞数け、Burker-Turk 氏 計算盤で，巨核球数は Fucks-Rosenthal 氏計算盤 で算定した。

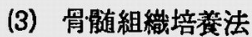

カバー・グラスを貼付した海野氏穴あきガラスの 穴の中飞, 健康人へパリン加血整を $1 / 2$ 皮下注射針 付ツヘルクリン注射器にて1 滴谪下し, 硝子棒て $15.0 \mathrm{~mm}$ の円形飞拡作，その中央飞 $1 \mathrm{~mm}^{9}$ 大の骨 髄組織の小片を置き，更に上から同様の注射器にて リンゲル氏液を等量に混じた鵎胎压㩁液を２滴谪下 する. 次にカパー・グラスで夏い,カナタバルサム で密封する。

斯くして出来た標本を， $37^{\circ} \mathrm{C}$ 㽟卵器内に静置し て扰くと，約20〜30分で血漿成分が固まり，標本を 動かしてる，培地の液状成分が動かなくなる。此の 時標本を裹返して支持体面を上にして静置する。斯 くすると增生帯の細胞が培地の液狀成分飞向つて增 生し，巨核球の観察が可能となる。

(4) 観察方法 (第 2 図)

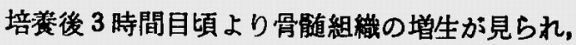
骨㟘道巨核球も游出し始めるが，私汒巨核球機能の最

\section{第 2 因 骨镂巨核球の運動及び栓球分離形態}

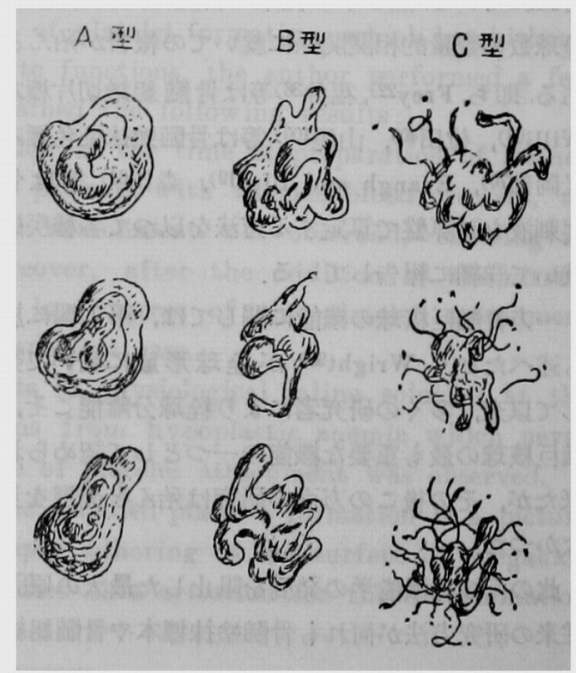


6活発な，培黄後12時間，18時間及び24時間目に於 て锂宗した.

観察は明視野頙微鏡を用いて, $37^{\circ} \mathrm{C}$ 保温箱内て 行つた。此の際培責標本は培地の支持体㑡を下にし て, 液状成分の附着面より観察し，余り長時間にわ たつて光線又は熱線を当てない様に注意した。

出現巨核球数及び巨核球能の判定方法は，教室 の角南，粟井等の方法に従つた． 即ち出現巨核球数 恃培美後絧胞增生带飞出現した巨核球数をるつて表 し，巨核球機能はその軍動形態及び栓球分離状態に より第 2 因に示す如く 3 型に分類した。即ち

A型 単純なる変形運動

B型 佦足運動

C 型 触手状乫起形成

(此の突起の尖端から栓球を分蜼する)

以上 $\mathrm{A}, \mathrm{B}, \mathrm{C}$ の 3 型飞就き，各々全出現巨核球数 反対する百分率を求めた。

\section{第3章実医成結}

第 1 管 健康人 (第 3 四)

栓球数（13.0 30.0万，平均20.5万）火異常学認

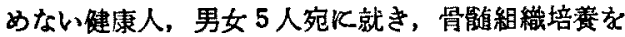
行い検査した. 先つ $1 \mathrm{~mm}^{3}$ 中の巨核球数は $30 \sim$ 102ケ，で平均61ケを示した。次に培鍰標本は1例 飞就き10枚を作慗し，出現巨核球数は 1 標本飞就い

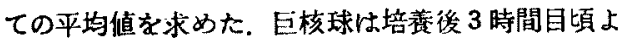
り次第飞細胞增生帯に游出し始め，時間と共飞增加

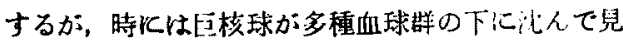
えなくなつたり，又は見落したりして減少する事も 有るので，ここで㥉数後12，18及ひ24時間目に於 て権祭し，その最高檤を以つて出現巨核球数とした。 键康人で出現巨核球数は2 10ケ，平均6.9ケであ つた. 次に巨核球機能は軽度珤形運動を行う A 型が 17 3096，平均24.796を示し，偽足運動を行5B型
第3図硉 康人

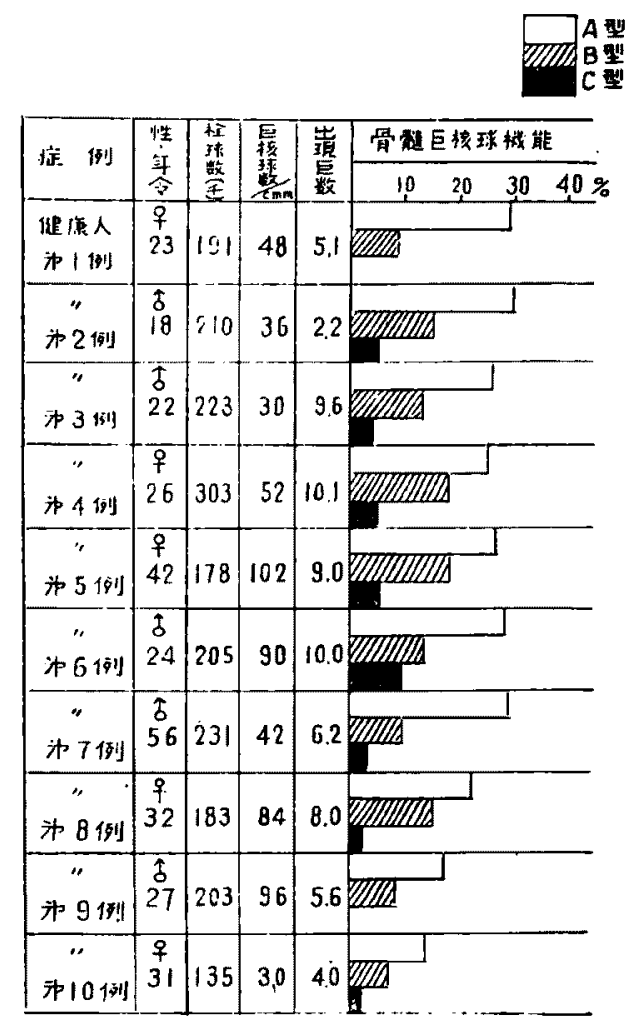

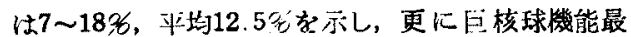
も立進し，突起方形成し，その触手状突起の尖端か

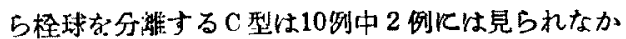
つたが, 残りの 8 例は夫ょ $2 \sim 9 \%$ 示し, 平均は 3.5\%であつた。

第 2 節 単純性紫病（第 1 表，第 4 脑） ウェルホーフ氏病つ巨核球㙨能に就いては教室の 仜南，粟井5)，本多55）等が詳紐に教告しているが， 私恃臨床症状の類似する笚純性柴斑病の 5 例任就き

第 1 表 単純性紫斑病患者の性血液像立び下巨核球像

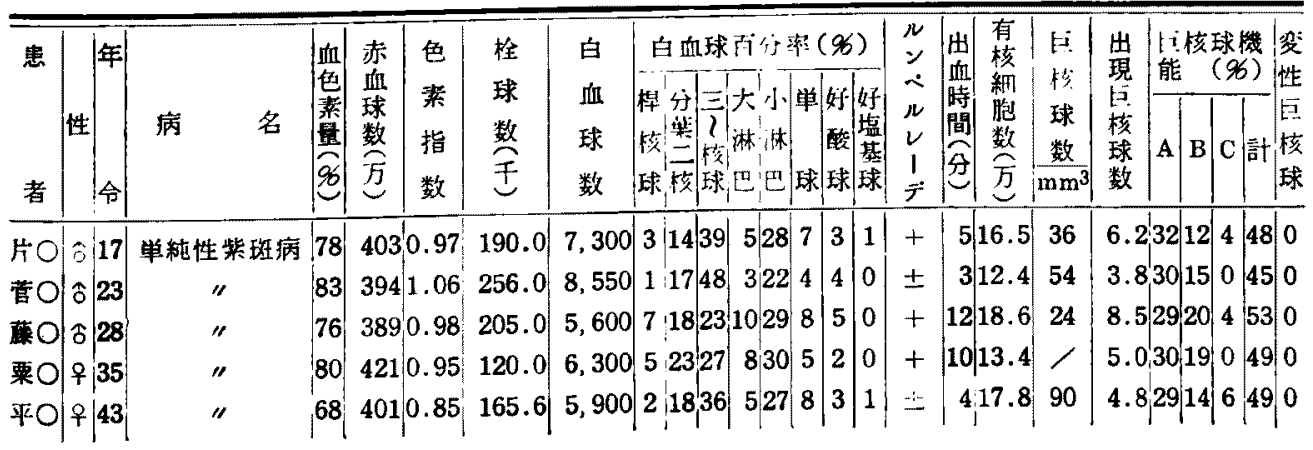




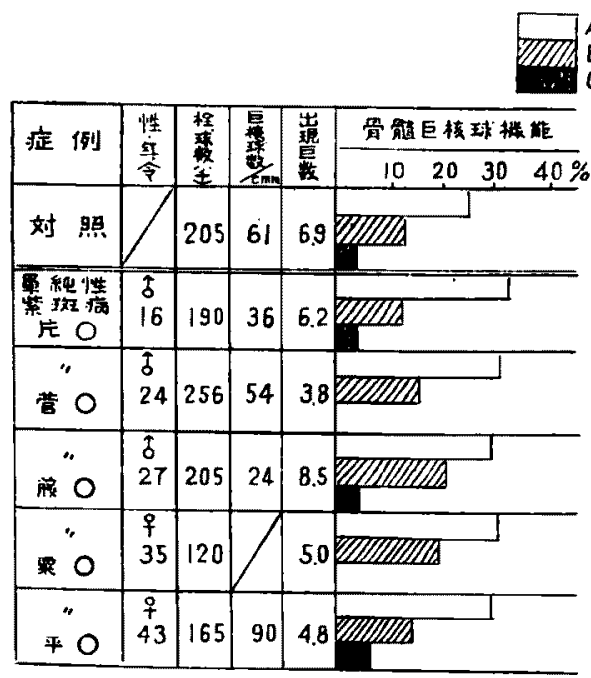

娭㚗した。栓球数は12.0〜25.0万で略く正常値を示

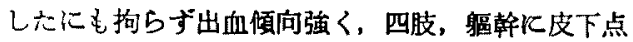
状出血を認めた例である。1 $1 \mathrm{~mm}^{3}$ 中の巨核球数は 24〜90ケと正常範囲にあつた, 出現巨核球数も3.8〜 8.5ケと正常值を示し，ウェルホーフ氏病に於て厚 々見られる如き著しい巨核球数の增多は見られなか つた，次に巨核球機能はA 型が29〜3296，B型が 12〜19\%6を示し，C型は 5 例中 2 例汇は出現しなか つたが他の3例では4〜6名と正常値を示した。

第 3 節 バンチ氏病（第 2 表，第 5 图）

本症患者の 8 例に就き蚞查した，尚，湯○，内○， 及び丸○の 3 例に於ては剔脾術の前後にわたり 2 回

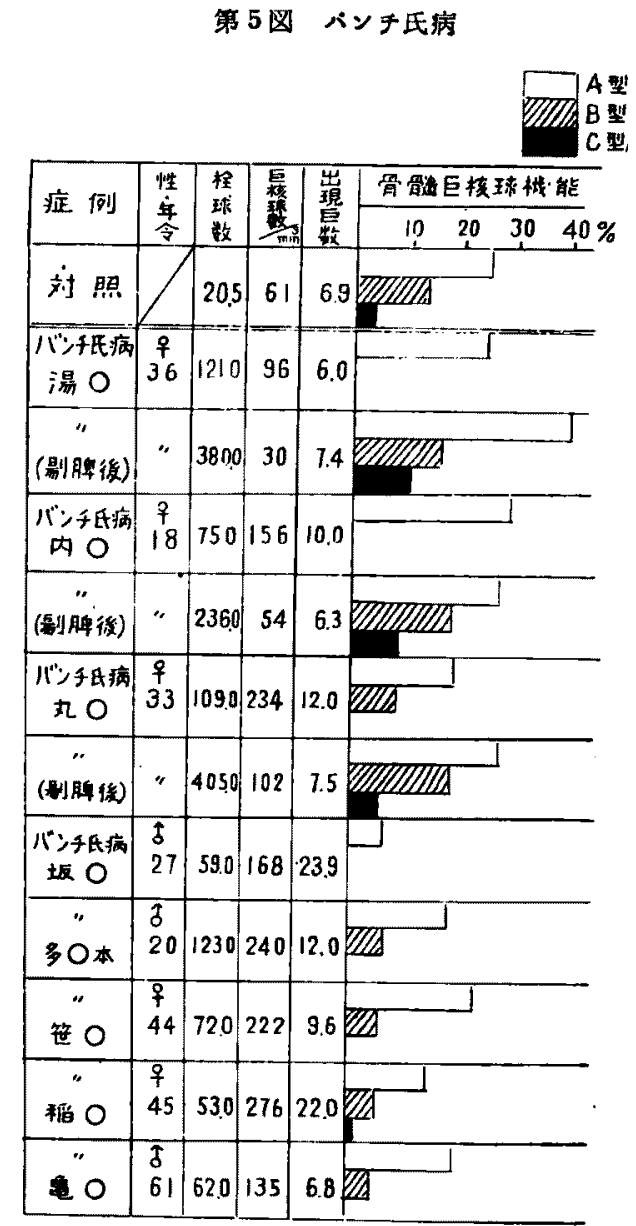

第 2 表 バンチ氏疾患者の末梢血液像並びに巨核球像

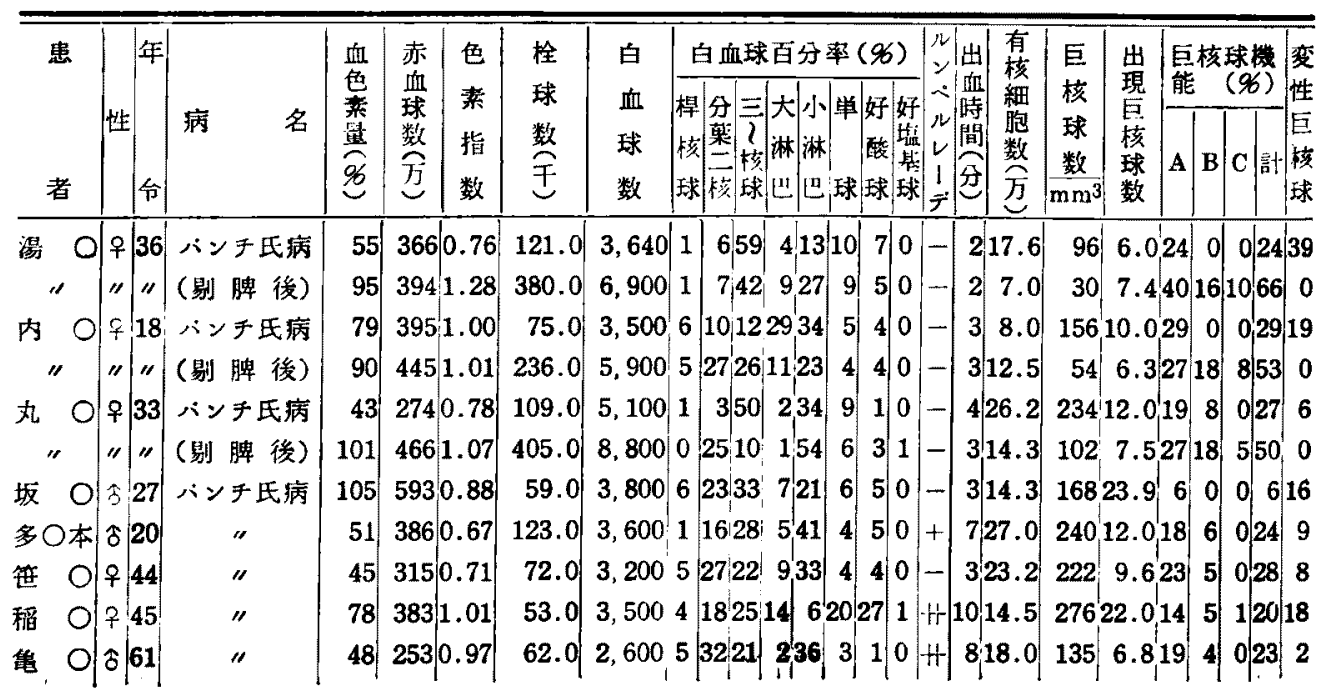


检査した。

栓球数け 8 例中 3 例は10.0 15.0万で，略々正常值を示したが，

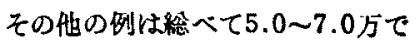
中等度の烃球減少を認めた. $1 \mathrm{~mm}^{3}$ 中の巨核球数は湯○が96ケで正常 值を示したが，他は何れす150ケ 以上飞增加し, 最大山坂○ひ 276 ケで正常の䄪 4 倍に增加した. 又 出現巨核球数。 $1 \mathrm{~mm}^{3}$ 中のE核 球数と同棣に增加し, 正常佔を示 したのは 3 例のみで, 10 20ケが 3 列，20ケ以上が 2 例も見られ最 高は坂○て23.9ケと著しく增加し た.

之に反して巨核球機能は著しく 低下し，C型は稻Oに於て1960認 めたのみで，他の症例では認めら

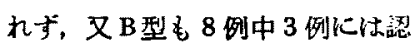
められず他の 5 例る最高 896 迄て 著明低低下した。A型も 8 例中 5 例で2096以示し，他の 3 例る 健捸人の平均值以下であつた. 次 亿本症患者巨核球て興味ある点は， 退行変性か可成り早期飞見られる 事で，健辰人巨核球で培琴後 36 48時間目頃より変性顆粒が出 現し，空胞家形成し，胞体の膨化 を見るか，本症に於ては12〜24時 間目で既变性顆柆の出現, 胞体 の膨化等の変性像を認めた。

湯O，内O，丸O，の3 例飞就 いては剔脾術後 3 週間目に再び検 査した. その結果, 栓球数は正常 值以上飞增加し, $1 \mathrm{~mm}^{3}$ 中の巨核 球数恃30,54,102\%, 出現巨核球 数も術前より減少し, 5 10ケで いずれす正常值に復した. 著しい 但下を示した巨核球機能る正常值 名示し，巨核球の早期变性像も見 られなくなつた。

第4節 再生不良性賓衈 （第 3 表）

13例の再生不良性實血患者の巨 核球敦き検查した。

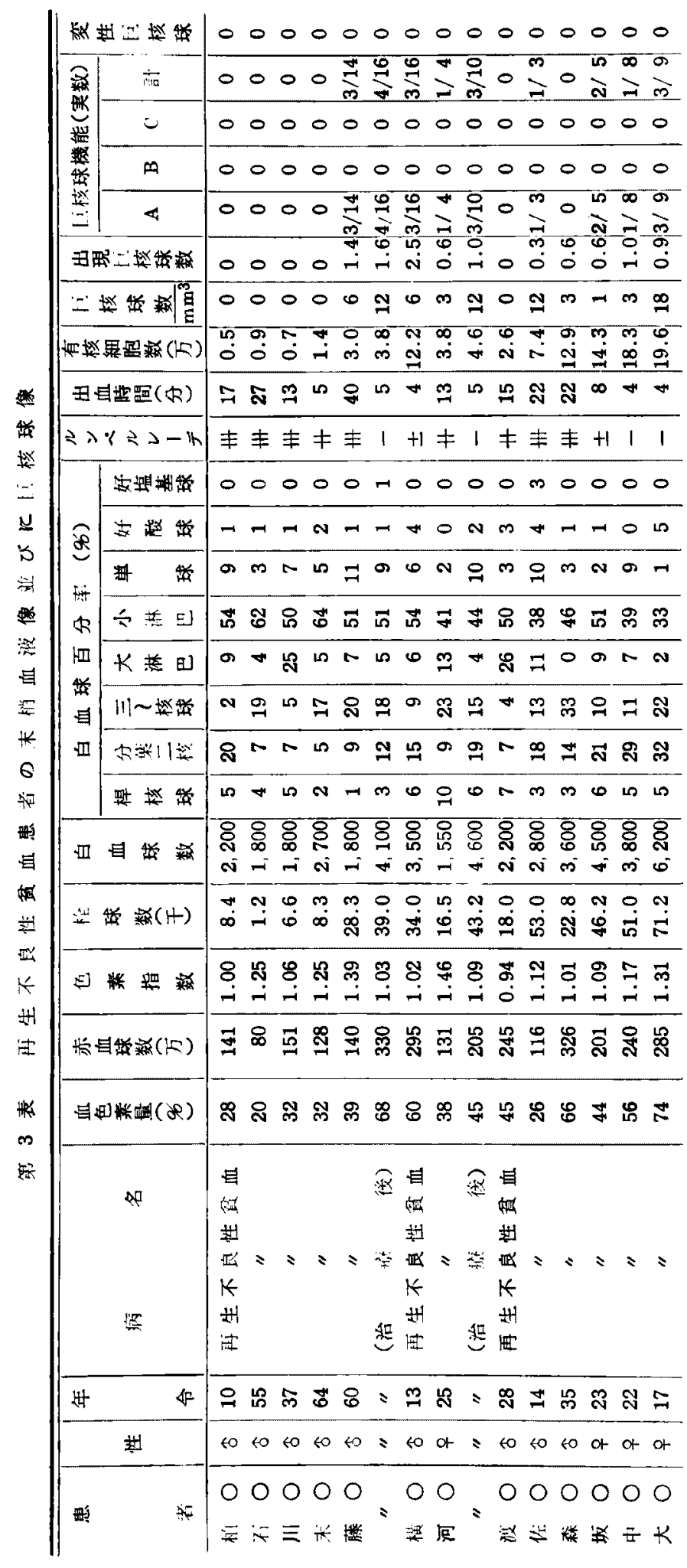


先ゔ相○, 石○, 川○及び末○ 9 4 例は何机子検查後 6 ケ月以内 に出血傾向增要し, 内啮諸脿器に 出血し，心信弱で死亡した極めて

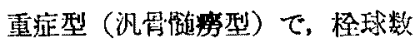
はいずれる 0.8 万以下に減少し， ルンペル・レーデ現象 (卅), 出

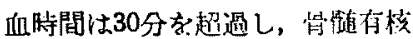
細胞数け0.5 1.4万で, 赤色格は すへて脂肪随で置換えられていた。 此の 4 例代於ては $1 \mathrm{~mm}^{3}$ 中の巨 核球数，出現巨核球数心紧汇 0 ケ

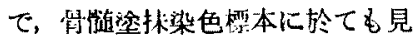

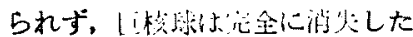
状热を示した。

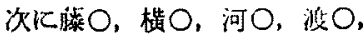

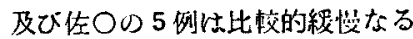

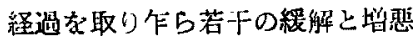
な繰返した症例で，栓球数は 1.5 －5.0万で出血倾向が出㳢した。 之等の例では， $1 \mathrm{~mm}^{3}$ 中のE核球 数は 0 〜 12ケと正常値に出遥力心 及ばないが前記重症例に比べると 多人，又出現巨核球数 1 例保 0 ケであつたが，他恬0.3〜2.5ケと

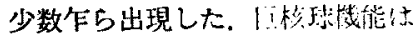
著しく低下し，活発なる機能な営 む, B型及びC型む全く润失し, A 型が僅かに出現したのみであつ た。尚，藤O，河O，の 2 例心輸 血, 間脳照射, ピタミン $B_{12}$ 注射

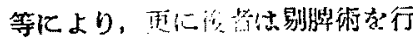
い末悄血渡像战可成り改善を見た が，栓球数江何ら变化を見ず，特

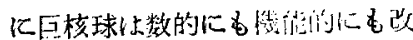
善を見なかつた。

㮏O，圾O，中○，及び大O， の 4 例去，末梢血液像で高度り 高色菜性賓血, 白血球及び烃球减 少を示し，各種の治療に反応しな

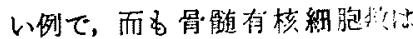
12.0 20.0万j と正常值を示し, 骨

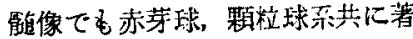

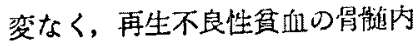
血球㧕留型飞属するものと考穴ら

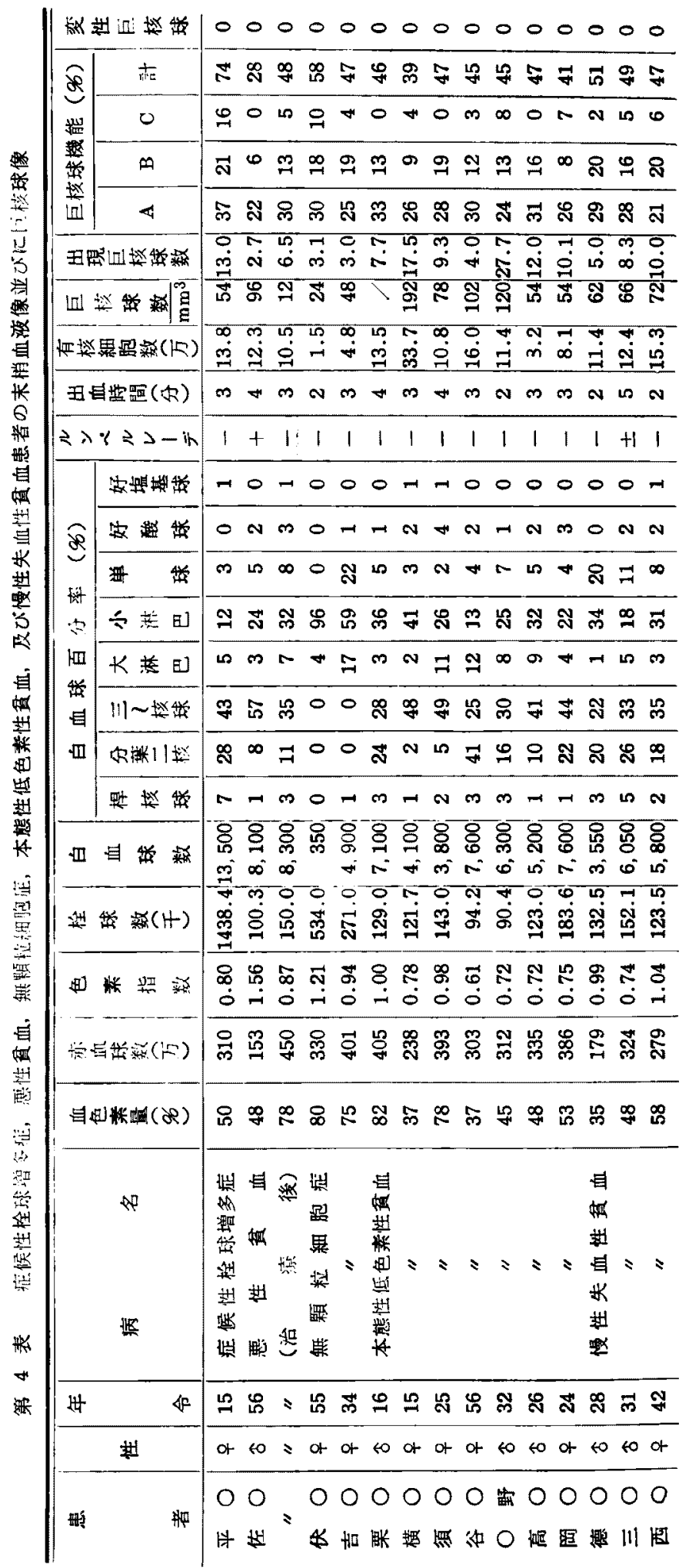


れる，斯かる極めて初期の再生不良性䨘们に於てる。

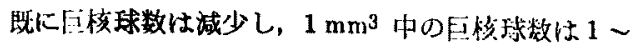

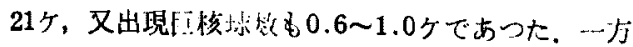

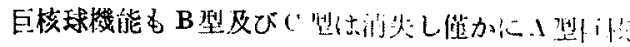
球が認められたに道ぎない。

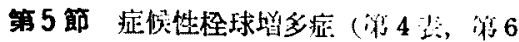
区)

本例は貫血，铰熱，及び蜰腫を主泝として入院し，

第 6 闵 淀侯性拴球增多㞗，要性费血及び 無顆粓稩胞症

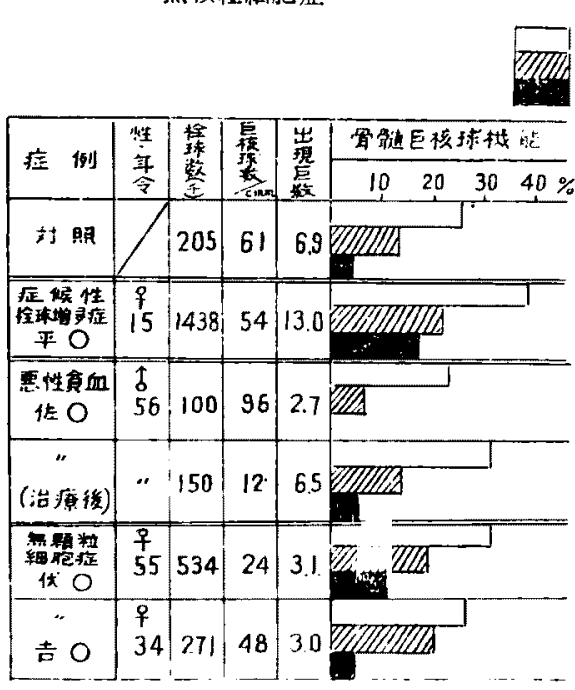

栓球数 143.8 万と商度の栓球增多を婄め大，各種検

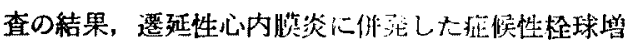

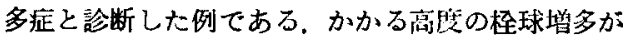

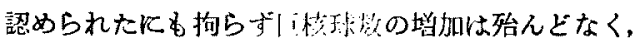
$1 \mathrm{~mm}^{3}$ 中の巨核球数は54ケで正行倬を示し, 出現 巨核球数け13ケで轻度の增加が見られた。一方，巨 核球械能は極めて话落て $\mathrm{A}$ 型 $37 \%, \mathrm{~B}$ 型 $21 \%$, C 型 16\%，脰74\%こ著しい儿進を小した。

第 6 節 悪性角任（第 4 素，第 6 図）

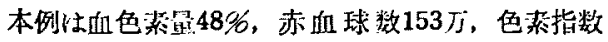
1.5 , 巨大赤芽球を $20.7 \%$ 。兄た，柽球粉け5.10.0万万 稍々減少を示した， $1 \mathrm{~mm}^{3}$ 中の!核球数は96ケで正 常值を示したが，出現闰核球数は1.8ケで成少示示 L, 巨核球㙨能注A 型23\%， B 型6\%， C 型 $0 \%$ と 軽度低下した。

ピタミン B12 $400 \gamma$ 注射後は, 血色案星, 赤血球 数, 色素指数は正常になり, 栓球数す15.0万人なつ た. 巨核球は， $1 \mathrm{~mm}^{3}$ 中の巨核球数 24 , 出現巨核 球数 6.5 ケで正常籁围汇あり，巨核球機能も正常に
茨した。

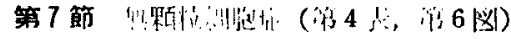

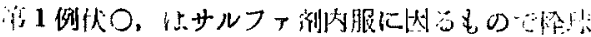

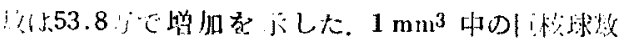

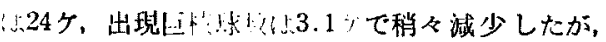

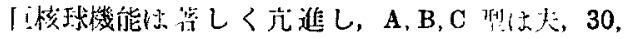
18，110告示た。次に吉○は原因不明の例で，栓

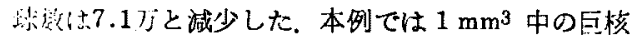
球炇，出現目核球数は18ケ，2.8ケと僅か汇減少し， 巨核球機能は A，B，C 年型は夫々 $25 ， 19 ， 4 \%$ と正 常であつた。

第 8 節 本態性低色落性貣血（第 4 表，第 7 図)

站に示す7例の患者に就き娭查したが，柽球数は

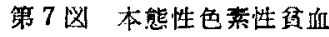

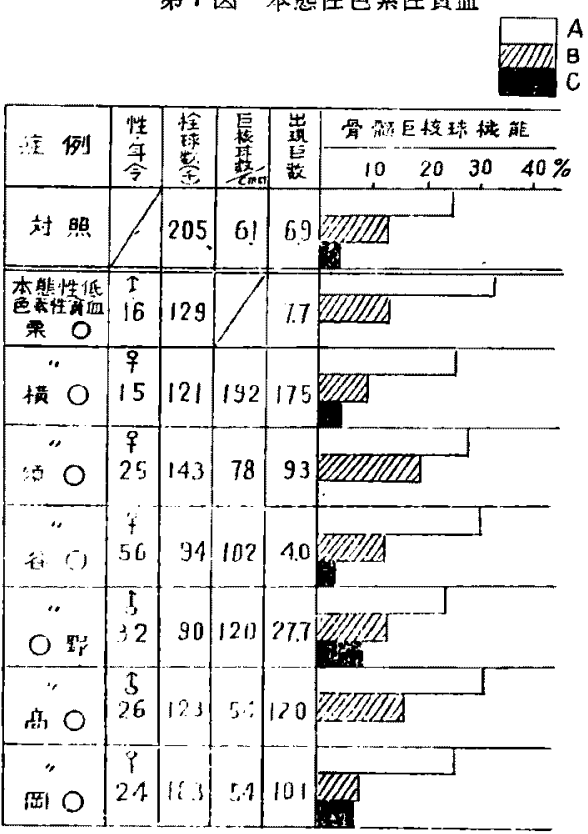

第 8 [四 慢性失血性争血

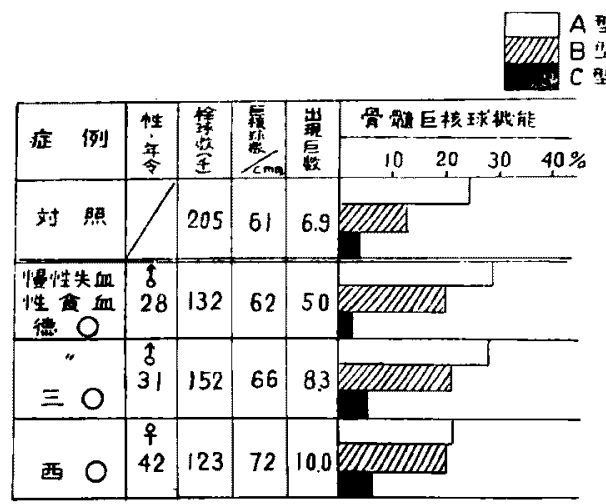


8.0 18.0万と稍々隇少の傾向が見られた。，巨核球 数は, $1 \mathrm{~mm}^{3}$ 中の巨核球数け $50 \sim 100$ ケか: 3 例, 100

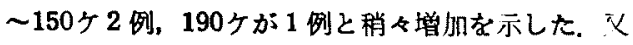
出現巨核球数 10 ケ以内 3 例，10 20ケ，3例20ケ 以上 1 洌で增加が見ら机た。镸校球機能はＡ，B，C 各型と略た正常檤を示した。

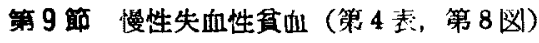

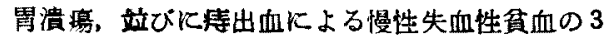
例で長期飞わたる失血で中等度の負血を見, 栓球数 :12.0 15.0万であつた。. 巨核球数は $1 \mathrm{~mm}^{3}$ 中の 巨核球数，出現巨核球数共に正常佰を示し，巨核球 機能む A, B, C 各型共に正常值を示した。

\section{第 4 章 総括泣ひに考菜}

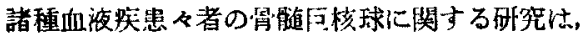

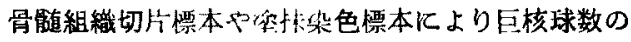

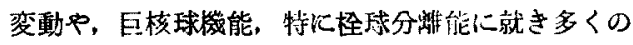
報告がなされた。

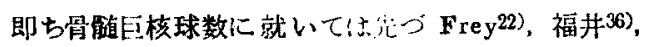
等が諸種血液疾患々者の骨檤組織切片標本て, 又 Evangh ${ }^{19)}$ ，森田64)，岡部70）等は骨檤第刺液老計算 盤で算定する方法により，一方 Rohr79)，Willi96) 等愲䯣染抹染色標本で巨核球数を求め，夫夕極め て詳細な報告を行つている，茲伦て Rohr ${ }^{79)} の$ 巨核球增多站びに巨核球减少を来与諸種疾患に就い ての分類を揭载すれば次の通りである，即ち，

(A) 巨核球增多を伴う諸疾患

1）諸種伝染病

2) 伝染性単球症

3）無顆粒細胞症

4) 真性多血症

5）慢性骨骮性白血病

6) ウェルホーフ氏病

7）栓球增多症

(B) 巨核球減少子伴亏諸疾患

1) 諸種伝染病の重症型

2）急性白血病

3）再生不良性貫血

4) 悪性實血

5）ビタミンA缺乏症

6)一種の巨核球減少症

以上の如くであり，その他諸氏の研究も略々これ に類似した結果を報告して扣り，諸種血液突患々者 の巨核球数に関する問題は, 既に解決された感があ る.
一方，之等諸種血液疾患々者の巨核球機能住関し て、系統的に研究きれた文献としては次の如きもの がある。即ち Schenker80)，Frey22) 等出諸種血液 实急々者の目核球索死後染色標本で観察し，胞体内 部の分野形成の状態により，潼川87）栓球の巨核 球周囲元の附着や，頜喰能飞より，又岡部70)，石 令38）等はアッール顆柆の状態から巨核球の機能に 就いて言及している. 最近, 森田64)等は所楞厂栓球分 朔像」によつて巨核梂機能を判定したが。この所㯰 「栓球分離像」は前編に於て述へた如く骨髄穿刺液中 の末梢血栓球が染抹標本䇚製時任巨核球の周囲又は 表面附着した人工的産物で，巨核球機能と云えな いことは明白である。

そこで私は骨野組織培法を用いて，巨核球の活 発な通動及び栓球分襍能を観察し，諸種血液矣患々 者の真の巨核球嘰能を検索し得大，以下突患別項 を分けて論ずる.

硉应人

10例の趾康人に就き検索したが，栓球数は平均 20.5 万で全く正常である. $1 \mathrm{~mm}^{3}$ 中の巨核球数は 30〜102ケ，平均61ケを示し，森田64〉 の若年者の平 均44.7ケ，老人はそれより稍々高いとの報告に比し， 稍々高い值を見たが，これは穿刺時の吸引力影䅉 されるもので，有核紐胞数も平均してやや多い値を 示した，組織培養に於ける出現巨核球数は，2.0〜 10.0 ケ，平均6.9ケで教室粟井の報告と略々一致し た. 次佢巨核球機能はA 型15 30\%, 平均 24.7\%, B 型7 18\%, 平均12.5\%, C 型 $2 \sim 9 \%$, 平均3.5 タ6を示した。

\section{単純性紫病}

本症は血管采の疾病で，血球系統倍化のない事 は衆知の事赛であるが，時にウェルホーフ氏病と籍 別に困難を来たす場合るある，本症に於ける栓球及 び巨核球関する文献は殆んど見られないが，僅か に福井 ${ }^{36)}$ が柽球数及び巨核球数は正常であると述 へておりり，又 Limarzi u. Schleicher(0) 性栓球数㤌 正常であるが, Purpura abdominalis 等極めて急 激な出血の見られる際には，二次的に巨核球数の增 多を来すと報告している. 私の実験でも栓球数及び 巨核球数には著変が見られず，巨核球機能も略々正 常であつた．斯くの如く骨㩆組織培意法によれば， ウェルホーフ氏病にに於ける巨核球数の著增及び高 度の巨核球機能低下等の所見と異なり，直ち飞篮別 できる. 
バンチ氏病

本应に於ける栓球及び巨核球仁就いて Rohr79)， Wintrobe97)，Limarzi59) 等は栓球数は可成り娍少 し，殆んんどが10.0万以下となり，巨核球山高度の

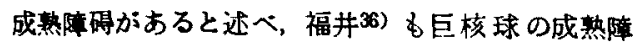

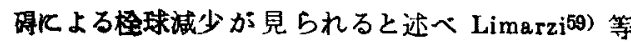
て替成している。滰川86) は本症の栓球減少は，巨 核球の成第䧊碍によるものではなく，分野形成障碍 即ら栓球分離能の低下によると述へている，之等の

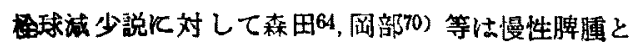
低色素寊血を主訴とするバンチ氏病を含し症候群に 於ては柽球诚少は苧ろ布で，栓球数は正常万至增加 し，巨核球数す增加し，所謂「烃球分誰像」る增加して いると述へている．私の症例では全例共桎球数は減 少し，砝んどは5.0〜10.0万で增加例は見られなか つた. 巨核球数は却つて增加し, $1 \mathrm{~mm}^{3}$ 中に273ケ る出現した例るあつた。 然し乍ら巨核球機能㐫高度 飞陪碍されて扣り，又変性像が早期飞見られた，之 等の所見から本症に於ける栓球城少怡，巨核球数㤌 增加する《る拘らず，個々の栓球形成能の障街心上 り惹起されたもので，恰もウェルホーフ氏病に於け る巨核球の態度に，類似している，又具制埕抹染色 標本に於ては，巨核球の成熟せるものが多く見られ， 澺川(87)，岡部70)の報告と一致したが，この様に成 熟巨核球でありながら，栓球形成学党まず，又極如 て早期汇変性に陥る点は，ウェルホーフ氏病に於け 万催栓球減少性物質に類似した团子が，患者の脾及 び血清中に存在する事によると考えられ本症患者 3 例で剔脾術後に巨核球数及び巨核球僟能が全く正常 值飞復した事は，脾及び血清中の催巨核球機能障碍 因子の存在を如赛に示するのと考えられる。 再生不良性負血

重症型の 4 例は, Rohr79) の Aplastische Form

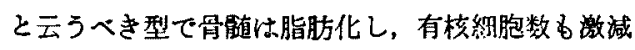
し，柽球数も0.8万以下Kなり，巨核球治んど完 全飞消失して扰り，Zitzmann101) の所謂巨核球勝症 (Megakaryophithise) の型を示したものと考えら れる.

次に比較的楥慢なる程過るとる型，及び骨倠有内血 球に変化の認められないで，末梢血像にのみ再生不

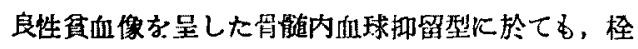
球隇少的高度に見られ，巨核球数の減少著朋で， 巨核球機能る高度飞低下しており，栓球系統の障码 が著明である. Road and Miller ${ }^{78)}$ 亦生不良性 角血の一病型としてMegakaryocytenmarkを示型
を報告しているが私の例中には見られなかつた，斯 くの如く骨鳁内赤芽球系及び顆柆球系細胞に未だ变 化の見られない時期（骨榷内血球抑留型）に既に骨 涟巨核球数及び巨核球機能に高度の障碍が見られ， 又治療に上り会血がある程度回復した後に於ても， 尚巨核球数及び機能に殆んど改善が兒られない事か ら本症に於ては栓球及び主核球系統が数的にも烧能 的にも最も早期に侵されるものと考えられる。

症候性烃球增多症

栓珪数が持続的飞增加を示す烃球增多症儿就いて ( G Guglielmo23), Epistein15), Uotila92) 等, 又本邦 に於て子狄尾24)，橋詰27，浜口20)等により詳䋖な 報告が見られ，その多くは真性多血症，慢性骨咉性 白血病，淋巴肉第腫症等に原因し，所謂 Megakaryocytic leukemia の範賬に含まれるものである。

一方栓球数の一時的增加を招く要約として食餉摄取， 手術時の侵焣，出産，発等等が挙けられるが，本例 は僊延性心内膜炎に併発した栓球增多症で栓球数心

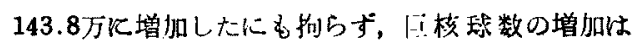
極く僅かて桎球数と巨核球数の間に比例関係忙見ら

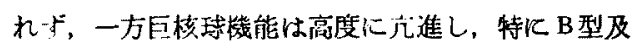

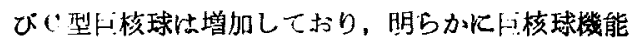
の䒕進による烃球增多と考えられる。

悪些頜血

本症患者の栓沓数炕関してはArneth4), Paddock72) アにより，中等度減少が埌告されている，次に本症 の巨核球に関して( 滝川(87), Dameshek86)等佢巨 核球数は減少し，栓球生成像は見られないと述一， Rohr79)，Jürgens44)，Eps(ein 16)，福井36) 等当巨核 球数の減少，竝びに核の過剩分核が見られると記载 している.

一方，岩男42)，森田64)，岡部70) 等屿巨核球の栓 烃生成像の減少及び核の過剩分核け認めているが， 巨核球数富ろ增加していると反对している．私の 症例栓球数減少し，下核球数も隇少を示し，巨核 待機能も亦低下しており，漓川87)，Rohr79，福井36) 等と類似せる所見丸得た，本症にビタミン $\mathrm{B}_{12}$ が卓 效を呈する事恬有名であるが，本例でもビタミン $\mathbf{B}_{12}$

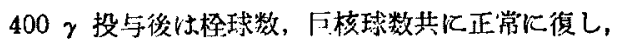
又巨核球機能も回復しC型が出現した。此の事実か ら本症患者の「核球機能の低下出，明らがピタミ ン $\mathrm{B}_{12}$ の缺乏によるすのである.

热顆粒行胞症

Wintrobe97)，Dameshek ${ }^{9)}$ 等出本症の栓球数は正 常であると記し，Heilmeyer28) 怔型的な本症では 
栓球增多があると述てている。一方福井36) は「レ」

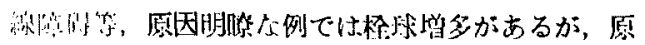

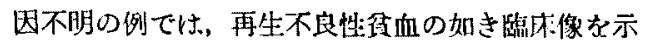
するのがある上報告している。私の割1例伏○，は

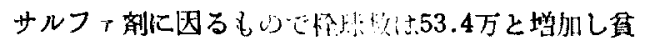
血なく、ACTH 投手により1週間で治檚したが，

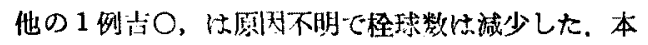
症の「核烈に就いて心，殆儿ど文献が兄られず僅か に福井36), Rohr79) が原因の明膫な例に於ては核 球数の增多と，栓球生成像が肍盛であると述へてい る、第 1 例は巨核球数の增多は見られなかつたか， 巨核球は極めて活発て，本例の栓球增多が等核球璣 能の亢進によるものである事を知つた。これは Rohr79）の云う中毒性顆粒球減少症の特徽として顆 粒球系細胞の機能娍退と, その他の赤芽球系及び栓

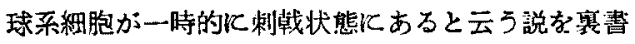
きしたすのと考立られる，尚第2 例は巨核球数，巨 核球機能は共に正常であつた。

本態性低色素性分血

本症の栓球数及び巨核球数に就いての文献い多く。 Patek73) Port u. Akiyama74)，Helber29) 等による と栓球数性略々正常であると云い，Wintrobe97) は 長期の鉄缺乏状態が続けば桯䍀減少がするるる述へ

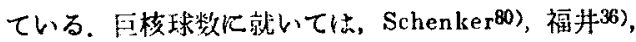

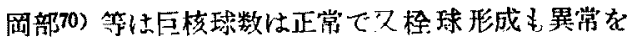
認めないと过へている，Rohr79) 。本症热者の巨榜

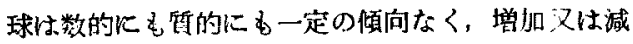
少し，成熟度もまちまちであるが，いずれも正常範 用を動摇しているに副ぎないと記载している。然し 私の例では巨核球機能は略々正常であり, 巨核球数 岕寧ろ增加したものが多かつたがー部には減少した ものも見られ一定しなかつた。

慢性失血性贫血

急恔失血性暑血に於ける烃球数及び巨核球の熊度

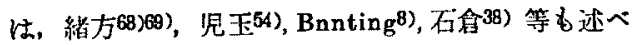
ている如く，極めて多彩である。然し乍ら癌朠, 胃

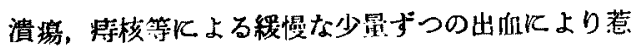
起された得血症に於ては，柽球系は澉感なる反応を
呈しない，即ち福井 ${ }^{36)}$ は烃球数，巨核球数は共に 如热夺見ずと云い，又 Limarzi u. Schleicher60) は 栓球数，巨核球数け正常丁'至稍々增加すると述へて いる. 私の例でも栓球数，巨核球数恃全く正常值を 示し，Fi恔永数も全く正常であつたか，これい失血 の程度が怪く、余り長期にわたらず，而も癌腫等の 悪海質を来与突患が含まれていない為と考えられる。

\section{第 5 章 結語}

1) 単純性紫海病では，烃球数，巨核数及び巨核 球機能に異常を認めなかつた。

2）バンチ氏病では，巨核球数恃著しく增加する 与巨核球機能怔著しく低下し，巨核球は早期化変性

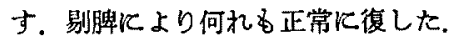

3）再生不良性實血では柽球数，巨核球数著しく 減少し，巨核球機能著明低下した。

4）症候性栓球增多症で栓球数は激增したが, 巨核球数恃著変なく，巨核球機能は極めて高度に元 進した。

5）覀生實血で忙巨核球数减少，巨核球機能の低 下があり，栓球数堿少した，ビタミン $\mathbf{B}_{12}$ 投与後 は正常復した。

6）無顆林細胞症の栓球增多例では巨核球数正常 なるも巨核球機能は艺進した，栓球娍少例では巨核 球粉，巨核球機能共飞正常であつた。

7) 本態性低色菜性負血では，栓球数は，正常で あり，巨核球数は稍ハ增加し，巨核球機能は正常で あつた。

8）慢性失血性貫血では烃球数，巨核球数及び巨 核球機能共に正常であつた。

終りと御想篤なる御指導と御校閲を睗つた恩師平 木教授立び角南俨師に深謝致します。

（尚本稿の要旨忙第19回日本血液学会飞於て㳦表 した.)

$$
\text { （文 献 後 揭） }
$$




\title{
Studies on the Function of Megakaryocytes in Patients with Various Blood Diseases by Means of Bone-Marrow Tissue Culture \\ Part 2. The Function of Megakaryocytes in Patients with Various Blood Diseases
}

By

\author{
Kunio SASAKI \\ Department of Internal Medicine Okayama University Medical School \\ (Director: Prof, Kiyoshi Hirakil
}

By means of bone-marrow tissue culture, the author studied the megakaryocyte count and the function of megakaryocytes in patients with various blood diseases, and obtained the following results :

1. In purpura simplex no abnormality could be observed in the megakaryocyte count or in the function of megakaryocytes.

2. In the cases of Banti's disease the megakaryocyte count was markedly increased, showing the increase of 2-5 times the normal count; and the megakaryocyte function was strikingly decreased, indicating the degeneration at an early stage. Even in these cases after splenectomy both the function and the number of megakaryocytes were found back to the normal level.

3. In hypoplastic anemia both the megakaryoccyte count and the function were found markedly decreased.

4. In the cases of symptomatic thrombocytosis, the megakaryocyte count increased slightly, while the function was greatly accelerated.

5. In pernicious anemia the megakaryocyte count showed an intermediate degree of decrease and likewise the megakaryocyte function was lowered. However, when vitamin $\mathrm{B}_{12}$ had been injected, both the number and function of megakaryocytes returned normal.

6. The cases of agranulocytosis showed the normal count of megaryocytes and normal or slightly-accelerated function.

7. In the cases of essential hypochromic anemia the megakaryocyte count was slightly increased but the megakaryocyte function was normal.

8. In the cases of chronic hemorrhagic anemia both the megakaryocyte count and function remained at the normal level. 